\title{
Pharmacological Prophylaxis of Venous Thromboembolism in Terminally III Patients: A Need or Futility?
}

\section{Profilaxia Farmacológica do Tromboembolismo Venoso em Doentes Terminais: Uma Necessidade ou um Desperdício?}

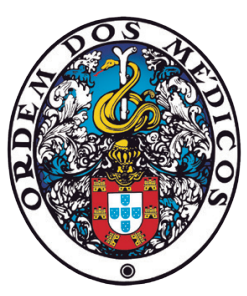

Laura SERRANITO ${ }^{1}$, Paulo REIS-PINA $\square^{2,3,4}$

Acta Med Port 2022 Feb;35(2):147-149 - https://doi.org/10.20344/amp.12932

\section{ABSTRACT}

The aim of this case is to clarify the need to maintain the terminally ill oncological patients who have had a thrombotic event in the course of their underlying disease under antithrombotic therapy. This case addresses a 63-year-old man with stage IV gastric antrum adenocarcinoma, completely bed-ridden and anticoagulated with subcutaneous enoxaparin for more than a year, following deep venous thrombosis of the left lower limb. After reviewing the literature, it was found that, for end-of-life patients, anticoagulation seems to have little benefit as the main objective is not the extension of life itself, but rather the preservation of the best quality of life through practices that are well established in the relief of suffering.

Keywords: Anticoagulants/therapeutic use; Enoxaparin; Fibrinolytic Agents; Palliative Care; Venous Thromboembolism/prevention \& control

\section{RESUMO}

O presente caso pretende clarificar qual a verdadeira necessidade de manter sob terapêutica anti-trombótica os doentes oncológicos terminais que tiveram um evento trombótico no decorrer da evolução da sua doença de base. O caso em questão aborda um doente de 63 anos com uma neoplasia do antro gástrico em estadio IV, totalmente acamado, hipocoagulado com enoxaparina subcutânea há mais de um ano, no seguimento de uma trombose venosa profunda no membro inferior esquerdo. Após revisão da literatura, constatou-se que em doentes em fim de vida, a anticoagulação parece ter pouco benefício, visto que o principal objetivo não é o prolongamento da vida, mas sim a preservação da melhor qualidade de vida possível através de práticas cuja evidência no alívio do sofrimento está bem documentada.

Palavras-chave: Agentes fibrinolíticos; Anticoagulantes/uso terapêutico; Cuidados Paliativos; Enoxaparina; Trombose Venosa/prevenção e controlo

\section{INTRODUCTION}

Advanced cancer patients are at increased risk of venous thromboembolism (VTE) due to age, local and distal spread of the malignancy and bed confinement, among other factors. ${ }^{1}$ The prevalence of asymptomatic VTE among palliative care (PC) patients has been found to reach $50 \%,{ }^{1}$ so VTE is considered clinically relevant only if it confers a patient-reported symptom burden. ${ }^{2}$ Many of the available guidelines advocate the implementation of thromboprophylaxis in cancer patients. However, in hospice care, where the priority goal is not life extension but assurance of the best quality of life trough symptom relief, the problem for cancer patients becomes ethically controversial. ${ }^{1}$

With this case we intend to discuss futility of starting antithrombotic therapy in terminal patients.

\section{CASE REPORT}

Male, 63 years-old, unemployed, with a prior clinical history of hypertension, dyslipidaemia, benign prostatic hyperplasia, obstructive sleep apnoea under continuous positive airway pressure and hepatitis $\mathrm{C}$ (cured). He was a former smoker (43 pack-years), in abstinence for over 30 years after a long history of intravenous drug use.
He was apparently well until December 2017, when he reported to his attending physician a weight loss of $20 \mathrm{~kg}$ in one month, heartburn and postprandial bloating (the latter with a more prolonged evolution and overlooked by the patient). In January 2018 he was diagnosed with stage IV gastric adenocarcinoma. Both chemotherapy (platinum agents) and radiotherapy were proposed as part of the palliative strategy. Due to repeated episodes of dysphagia between March 2018 and June 2019, caused by tumour ingrowth, he had four unpainted transpyloric metal prostheses placed. In April 2018 he had deep venous thrombosis (DVT) in the left lower limb and since then he had been treated with subcutaneous (SC) enoxaparin 60 mg. In October 2018, given the advanced stage of the gastric cancer and his reduced performance status (capable of only limited self-care, confined to bed or chair $50 \%$ or more of his waking hours), all diagnostic and disease-specific therapeutic attitudes with curative intent were discontinued. In February 2019, he began PC consultation at the referral hospital.

Six days before PC unit admission, the patient presented dysphagia for solids, increasing dyspnoea and hyperactive delirium. At that time, he weighed $51 \mathrm{~kg}$. His regular

\footnotetext{
1. Family Health Unit "Delta”. Agrupamento de Centros de Saúde de Lisboa Ocidental e Oeiras. Paço d'Arcos. Portugal.

2. Palliative Care Unit "Bento Menni". Casa de Saúde da Idanha. Sintra. Portugal.

3. Medical School. Universidade do Minho. Braga. Portugal.

4. Medical School. Universidade de Lisboa. Lisboa. Portugal.

$\triangle$ Autor correspondente: Paulo Reis-Pina.paulopina@medicina.ulisboa.pt
}

Recebido: 08 de outubro de 2019 - Aceite: 05 de setembro de 2020 - First published: 08 de fevereiro de 2021 - Online issue published: 01 de fevereiro de 2022 Copyright @ Ordem dos Médicos 2022 
medicines were omeprazole $20 \mathrm{mg} q d$, gabapentin 300 $\mathrm{mg}$ bid, metoclopramide $10 \mathrm{mg}$ tid, furosemide $60 \mathrm{mg} \mathrm{qd}$, spironolactone $100 \mathrm{mg}$ qd, levomepromazine $2.5 \mathrm{mg}$ qd; all of these were administered per os.

In July 2019, he was admitted to a PC unit for symptomatic control. Upon admission to the unit, the patient was conscious, oriented, apyretic, and pale. He had bilateral stasis; painless distended abdomen with central tympanism and peripheral dullness; lower limb oedema up to the thigh root. Subjectively and according to the Edmonton Symptom Assessment System (self-assessment, increasing intensity from zero to ten), the patient had: pain $=8$, tiredness $=9$, nausea $=3$, depression $=8$, anxiety $=2$, appetite $=5$, drowsiness $=4$, wellbeing $=8$, shortness of breath $=7$, constipation $=4$. According to the Palliative Performance Scale (PPS), he had an estimated physical performance of $30 \%$.

A medication review was performed: SC (dexamethasone $4 \mathrm{mg}$ bid, butylscopolamine $20 \mathrm{mg}$ tid, haloperidol 5 $\mathrm{mg} q d$, furosemide $20 \mathrm{mg} \mathrm{qd}$ ), per os (lactulose $15 \mathrm{mLI}$ tid, orodispersible omeprazole $20 \mathrm{mg} q d$ ) and transdermal fentanyl $50 \mu \mathrm{g} / \mathrm{h} q d$.

The patient died two days after PC unit admission.

\section{DISCUSSION}

The case concerns a man with stage IV gastric antrum adenocarcinoma, who had DVT in the left lower limb in April 2018, and was bed-ridden.

This patient was still on treatment when DVT was diagnosed. Patients with inoperable locally advanced and/or metastatic stage IV cancer should be considered for systemic treatment, like chemotherapy, which has shown to improve survival and quality of life compared with the best supportive care alone. ${ }^{3}$ It is known that adenocarcinomas and advanced disease, ${ }^{4}$ as well as chemotherapy with platinum or antiangiogenic agents, ${ }^{3,5}$ are associated with higher risk of cancer related VTE.

By the time of DVT diagnosis, three things were a given: the patient was receiving chemotherapy, his performance status was low, and cancer disease was in progression. All of these influence the anticoagulation decision. ${ }^{6} \mathrm{It}$ is not possible to know whether direct oral anticoagulants were added as options for VTE treatment. ${ }^{7}$

The standard initial treatment of an acute episode of VTE in cancer patients consists of SC low molecular weight heparin (LMWH) at a dose that is adjusted to body weight and long-term treatment is recommended. ${ }^{8}$ For cancer patients receiving chemotherapy, indefinite LMWH treatment should be discussed with them. ${ }^{9-12}$ The usual dose of SC enoxaparin must be $1.5 \mathrm{mg} / \mathrm{kg}$ od or $1.0 \mathrm{mg} / \mathrm{kg}$ bid, either for prophylaxis or treatment purposes. ${ }^{9}$ Before admission into the PC unit his weight was $51 \mathrm{~kg}$, which means that he was on a sub-therapeutic prophylactic scheme. Reasons for that were not elicited. Portuguese guidelines recommend that in men with low weight (below $57 \mathrm{~kg}$ ), SC injections of LMWH should be used with caution, given the uncertainty of the dose. ${ }^{9}$

Some elements for consideration in the decision of not treating or not using prophylaxis for VTE are: patient refusal; non-therapeutic advantages (limited survival, high risk, unplanned oncologic interventions, etc.); non-palliative benefits (for instance, dyspnoea is already controlled and/or pain, associated to leg swelling, is reduced); and unreasonable burden of anticoagulation treatment (painful injections, frequent monitoring with phlebotomies, etc.). ${ }^{10}$

For people who are having PC pharmacological VTE prophylaxis is recommended and should be reviewed daily, considering the views of the person, family members or carers and the multidisciplinary team. ${ }^{11}$ In PC, the likely life expectancy should always be considered before VTE prophylaxis. ${ }^{11}$

In patients in $\mathrm{PC}$, temporary increases in thrombotic risk factors and risk of bleeding should impact decisions regarding the use of thromboprophylaxis. ${ }^{11,13}$ This risk is greatly increased in cancer patients due to the tumour itself, renal and liver failure, malnutrition or the metastatic process involving organs participating in homeostasis (liver, bone marrow). ${ }^{1}$ Most patients with metastatic cancer disease remain anticoagulated until their death. Despite the limitations of retrospective data across healthcare settings, it appears that anticoagulation, as death approaches, confers a significant bleeding risk without the additional benefit of preventing VTE symptoms. ${ }^{14}$

Few doctors believe that patients at the end of life should always be treated for VTE. ${ }^{15}$ Some argue it is reasonable to maintain anticoagulation, if the patient agrees to it, is somewhat independent in carrying out activities of daily living and tolerates SC injections. ${ }^{16}$ However, if the patient declines therapy, has a low performance status or is entering the dying phase, discontinuing anticoagulation is reasonable. ${ }^{16}$ Many doctors wondered if it was 'fair' to give a daily SC injection of LMWH to a patient in the last few weeks of life. ${ }^{15}$ The treatment for VTE in PC patients is intrinsically bound to the doctor's own moral and ethical framework..$^{15}$ It could be argued that clinicians who withhold LMWH injections because they do not want to subject the patient to the perceived discomfort of the injection - are taking a moral decision which may run contrarily to the patient's own choice. ${ }^{15}$ The pivotal variable that influences a doctor's decision to prescribe SC injections of LMWH appears to be the prognosis of the patient, with treatment said to be largely unbeneficial at end of life. This is because, in the short time left, the patient's symptoms may not be ameliorated by LMWH injections. ${ }^{15}$

When this patient was admitted to the PC unit, he had been anticoagulated for over a year and had had a progressive deterioration of his clinical condition, with no perspective of cure. Upon admission, survival was estimated in less than three weeks according to the Palliative Prognostic Index (dysphagia, dyspnoea, delirium, oedema, PPS $30 \%$ ). ${ }^{17}$ The PC unit team decided not to prescribe VTE prophylaxis because the patient was in his dying process. Indeed, he died two days after PC unit admission. VTE prophylaxis should not be offered to people in the last days of life. ${ }^{11}$ 


\section{CONCLUSION}

In PC the ethical principle of "nonmaleficence" should be of paramount consideration in ethical-clinical decision making.

There is no robust data supporting the use of thromboprophylaxis in hospice. It seems that thromboprophylaxis in this group of patients should not be routine practice. ${ }^{1}$ The indications for anticoagulation should be assessed individually, with previous assessment of VTE risk, comorbidities and possible hemorrhagic complications. ${ }^{1}$ With that in mind, the final decision to initiate and maintain anticoagulation should be based largely on patient's own opinion, if mentally able to decide in their best interest. ${ }^{15}$

\section{AUTHORS CONTRIBUTION}

LS, PRP: Both authors contributed equally to the conceipt of the work, draft of the paper, criticial review and approval of the final version.

\section{PROTECTION OF HUMANS AND ANIMALS}

The authors declare that the procedures were followed

\section{REFERENCES}

1. Zabrocka E, Wojtukiewicz MZ, Sierko E. Thromboprophylaxis in cancer patients in hospice. Adv Clin Exp Med. 2018;27:283-9.

2. White C, Noble SI, Watson M, Swan F, Allgar VL, Napier E, et al. Prevalence, symptom burden, and natural history of deep vein thrombosis in people with advanced cancer in specialist palliative care units (HIDDen): a prospective longitudinal observational study. Lancet Haematol. 2019;6:e79-e88.

3. Smyth EC, Verheij M, Allum W, Cunningham D, Cervantes A, Arnold D. Gastric cancer: ESMO Clinical Practice Guidelines for diagnosis, treatment and follow-up. Ann Oncol. 2016;27:v38-v49.

4. Lyman $\mathrm{GH}$. Venous thromboembolism in the patient with cancer. Cancer. 2011;117:1334-49.

5. Barni S, Labianca R, Agnelli G, Bonizzoni E, Verso M, Mandalà M, et al. Chemotherapy-associated thromboembolic risk in cancer outpatients and effect of nadroparin thromboprophylaxis: results of a retrospective analysis of the PROTECHT study. J TransI Med. 2011;9:179.

6. Noble SI, Shelley MD, Coles B, Williams SM, Wilcock A, Johnson $\mathrm{MJ}$, et al. Management of venous thromboembolism in patients with advanced cancer: a systematic review and meta-analysis. Lancet Oncol. 2008;9:577-84.

7. Key NS, Khorana AA, Kuderer NM, Bohlke K, Lee AYY, Arcelus JI, et al. Venous thromboembolism prophylaxis and treatment in patients with cancer: ASCO Clinical Practice Guideline Update. J Clin Oncol. 2020;38:496-520.

8. Khorana AA, Carrier M, Garcia DA, Lee AY. Guidance for prevention and treatment of cancer-associated venous thromboembolism. J Thromb Thrombolysis. 2016;41:81-91.

9. Grupo de Estudos de Cancro e Trombose (GESCAT). Recomendações portuguesas para a profilaxia e tratamento do tromboembolismo venoso (TEV) no doente oncológico. GESCAT; 2014. [accessed 2020 Feb 23]. Available from: https://gescat.pt/profissionais-de-saude/ according to the regulations established by the Clinical Research and Ethics Committee and to the 2013 Helsinki Declaration of the World Medical Association.

\section{DATA CONFIDENTIALITY}

The authors declare having followed the protocols in use at their working center regarding patients' data publication.

\section{PATIENT CONSENT \\ Obtained.}

\section{COMPETING INTERESTS}

The authors have declared that no competing interests exist.

\section{FUNDING SOURCES}

This research received no specific grant from any funding agency in the public, commercial, or not-for-profit sectors.

recomendacoes-para-a-profilaxia-e-tratamento-do-tev/.

10. Streiff MB, Holmstrom B, Angelini D, Ashrani A, Bockenstedt PL, Chesney $C$, et al. Cancer-associated venous thromboembolic disease. NCCN Guidelines Version 1.2019. The National Comprehensive Cancer Network, Inc.; 2019. [accessed 2020 Feb 28]. Available from: https:// www.nccn.org/professionals/physician_gls/pdf/vte.pdf.

11. National Institute for Health and Care Excellence (NICE). Venous thromboembolism in over 16s: reducing the risk of hospital-acquired deep vein thrombosis or pulmonary embolism. NICE guideline [NG89]; 2019. [accessed 2020 Feb 28]. Available from: www.nice.org.uk/ guidance/ng89.

12. Mandalà M, Falanga A, Roila F; ESMO Guidelines Working Group. Management of venous thromboembolism (VTE) in cancer patients: ESMO Clinical Practice Guidelines. Ann Oncol. 2011;22:vi85-92.

13. Tardy B, Picard S, Guirimand F, Chapelle C, Danel Delerue M, Celarier $\mathrm{T}$, et al. Bleeding risk of terminally ill patients hospitalized in palliative care units: the RHESO study. J Thromb Haemost. 2017;15:420-8.

14. Noble S, Banerjee S, Pease NJ. Management of venous thromboembolism in far-advanced cancer: current practice. BMJ Support Palliat Care. 2019 (in press). doi: 10.1136/bmjspcare-2019-001804.

15. Sheard L, Prout H, Dowding D, Noble S, Watt I, Maraveyas A, et al. The ethical decisions UK doctors make regarding advanced cancer patients at the end of life--the perceived (in) appropriateness of anticoagulation for venous thromboembolism: a qualitative study. BMC Med Ethics. 2012;13:22.

16. Tran QN. Role of palliative low-molecular-weight heparin for treating venous thromboembolism in patients with advanced cancer. Am J Hosp Palliat Care. 2010;27:416-9.

17. Morita T, Tsunoda J, Inoue S, Chihara S. Survival prediction of terminally ill cancer patients by clinical symptoms: development of a simple indicator. Jpn J Clin Oncol. 1999;29:156-9. 